\title{
ENVIRONMENTAL FACTORS AND THE DISTRIBUTION OF MANSONELLIASES IN SOUTHERN VENEZUELA
}

\author{
GÓMEZ J.* \& GUERRERO R.**
}

\section{Summary :}

The distribution of mansonelliases and their relation to various quantitative criteria were determined through the study of 1,057 subjects in 17 localities in ten regions of Amazonas State and Bolivar State. The total prevalence among the blood samples, determined through the Knott technique, was $18.54 \% .11 .26 \%$ were parasited by Mansonella perstans, $9.93 \%$ by Mansonella ozzardi, and $2.63 \%$ by both species. The average of microfilaremia was $48.19 \mathrm{mf} / \mathrm{mL}$ of blood in M. perstans and $13.79 \mathrm{mf} / \mathrm{mL}$ in $M$. ozzardi. In the regions studied, M. ozzardi has a wider area of distribution than $M$. perstans. Prevalence, average number of parasites per host, and the infection index have a positive and statistically significant correlation with the total annual precipitation mean for each region for $M$. perstans; in the case of $M$. ozzardi the quantitative parameters are positively correlated with the altitude of each region, this correlation being statistically significant. With respect to type of vegetation, M. perstans had a higher infection index in Amazonian caatinga transition in pluvial lowland forest, and $M$. ozzardi in semideciduous forest of the alisio type. Therefore two types of transmission, M. ozzardi-Simulium and M. perstans-Culicoides are suggested.

KEY WORDS : mansonelliasis, Venezuela, distribution, vegetation types.

\section{INTRODUCTION}

$\mathrm{M}$ ansonelliases are endemic in several regions of Africa, the Caribbean and Latin America. In South America it has been reported in Venezuela, Colombia, Brazil, Guyana, Suriname, Argentina and Peru (Sasa, 1976; Hawking, 1979), although in most of these countries its prevalence and geographical distribution, as well as the environmental factors determining distribution, have yet to be defined. However, many of the areas in South America where mansonelliases are endemic lie within the Amazon basin (Kozek et al., 1982b).

\footnotetext{
* Centro Amazonico para la Investigación y Control de Enfermedades Tropicales (CAICET), Ave. Perimetral, Pto. Ayacucho, Edo. Amazonas, Venezuela.

** Instituto de Zoología Tropical, Facultad de Ciencias, Universidad Central de Venezuela, P.O. Box 47058, Caracas 1041A, Venezuela. Correspondence: R. Guerrero.

Tel.: (582)-372-5187 - Fax: (582)-605-1204.

Email: rguerrer@strix.ciens.ucv.ve
}

Résumé : Facteurs ENVIRONNEMENTAUX ET DISTRIBUTION DES MANSONELLOSES DANS LE SUD DU VENEZUELA

La distribution des mansonelloses et leurs relations à divers critères quantitatifs ont été déterminés à partir de l'étude de 1057 sujets dans 17 localités de dix régions des États d'Amazonas et de Bolivar. La prévalence dans les prélèvements sanguins, déterminée selon la technique de Knott, était de 18,54\%. 11,26\% étaient parasités par Mansonella perstans, 9,93\% par Mansonella ozzardi, et 2,63\% par les deux espèces. Le taux moyen de microfilarémie était de $48,19 \mathrm{mf} / \mathrm{mL}$ pour $\mathrm{M}$. perstans et de $13,79 \mathrm{mf} / \mathrm{mL}$ pour M. ozzardi. Dans les régions étudiées, $M$. ozzardi a une aire de répartition plus vaste que $M$. perstans. Pour M. perstans, la prévalence, le nombre moyen de parasites et l'index d'infection ont une corrélation positive et statistiquement significative avec la moyenne des précipitations annuelles de chaque région. Dans le cas de M. ozzardi, les paramètres quantitatifs sont corrélés de façon positive et statistiquement significative avec l'altitude de chaque région. Au regard du type de végétation, l'index d'infection de $M$. perstans est plus élevé dans lest forêts basses et humides, et celui de $M$. ozzardi dans les forêts semi caduques. En conséquence, deux types de transmission sont suggérés: $M$. ozzardi-Simulium et $M$. persistans-Culicoides.

MOTS CLÉS : mansonelloses, Venezuela, distribution, végétation.

In Amazonas State in Venezuela, it has been reported that Mansonella (Mansonella) ozzardi (Manson, 1897) and Mansonella (Esslingeria) perstans (Manson, 1891) mainly affect the ethnic groups that inhabit the region (Baumgartner, 1955; Beaver et al., 1976; Botto et al., 1983; Formica \& Botto, 1990).

These studies show that mansonelliases are widely distributed throughout Amazonas State. However, with the exceptions of Botto et al. (1983) and Formica \& Botto (1990), they underestimate the infected population because the diagnostic techniques used were not very sensitive. Thus there is a need to evaluate the real situation of these filarial parasites by means of a technique of proven sensitivity, such as the Knott technique (Botto et al., 1983; Raccurt et al., 1982).

Likewise, there have not been any studies which correlate the distribution of these parasites, along with epidemiological indexes such as prevalence and parasitical load, to environmental factors like vegetation and rainfall among others.

For this reason we have carried out studies in different parts of Amazonas State in Venezuela and in one 
locality in Bolivar State in order to determine the prevalence, parasitical load and precise taxonomic identity of the Mansonella species involved, and the characteristics of the different regions in terms of their vegetation, precipitation and altitude, with the aim of contributing to the framework of current knowledge about these parasites in the areas in question.

\section{MATERIALS AND METHODS}

\section{AREA OF STUDY}

T This mainly comprises Amazonas State, with one adjacent locality in Bolívar State.

The Amazonas State is located in the south of Venezuela and has an area of 175,750 square kilometres. It lies in the basin of the Orinoco and Negro rivers, upstream from the convergence of the Orinoco and Meta rivers, on the frontier with Brazil and Colombia.

This region is characterised by high average temperatures, abundant and persistent rain, high relative humidity and an extraordinary variety of vegetation, especially of the forestal type. Maximum precipitation occurs in the south-west of the state, while the driest parts are in the south-east and north-west.

It has been estimated that $93 \%$ of the region is covered by forest with two to four layers of vegetation, the lower levels consisting of shrubbery and the upper levels of big trees. The rest of the surface $(7 \%) \mathrm{com}^{-}$ prises savannahs, rivers and rocky outcrops (Boada, 1983).

The samples were collected from 17 localities distributed in 11 areas characterised according to their vegetation, following Huber (1982). The annual mean rainfall and annual mean temperatures given are calculated from figures provided by the Direction of Hidrology and Meteorology at the Venezuelan Environment Ministry.

The areas are as follows (Fig. 1):

A - Rivers Temi and Atacavi, at the source of the Atabapo river $\left(26.74^{\circ} \mathrm{C}, 100\right.$ metres above sea level).

B - Upper Orinoco, above the village of Ocamo $\left(26.75^{\circ} \mathrm{C}\right.$, $150 \mathrm{~m})$.

C - Cejal, between La Esmeralda and Tama-Tama $\left(27.02^{\circ} \mathrm{C}\right.$, $100 \mathrm{~m}$ ).

D - River Cunucunuma, between Tama-Tama and Culebra $\left(27.02^{\circ} \mathrm{C}, 220 \mathrm{~m}\right)$.

E - Isla Ratón, an island in the Orinoco river south of Puerto Ayacucho $\left(27.03^{\circ} \mathrm{C}, 100 \mathrm{~m}\right)$.

F - River Cataniapo, downstream $\left(27.03^{\circ} \mathrm{C}, 100 \mathrm{~m}\right)$.

$\mathrm{G}$ - Rivers Cuao, Sipapo and Autana, downstream and river mouths $\left(27.24^{\circ} \mathrm{C}, 100 \mathrm{~m}\right)$.

$\mathrm{H}$ - Upper Ventuari, the head of the river above Cacuri $\left(27.68^{\circ} \mathrm{C}, 500 \mathrm{~m}\right)$.
I - Upper Cuao, midstream (no climatological station, so the figures for $G$ are used).

$\mathrm{J}$ - River Parguaza, downstream in Bolívar State $\left(27.03^{\circ} \mathrm{C}\right.$, $100 \mathrm{~m})$.

$\mathrm{K}$ - The Topocho stream, close to Parhueña village $\left(27.03^{\circ} \mathrm{C}, 100 \mathrm{~m}\right)$.

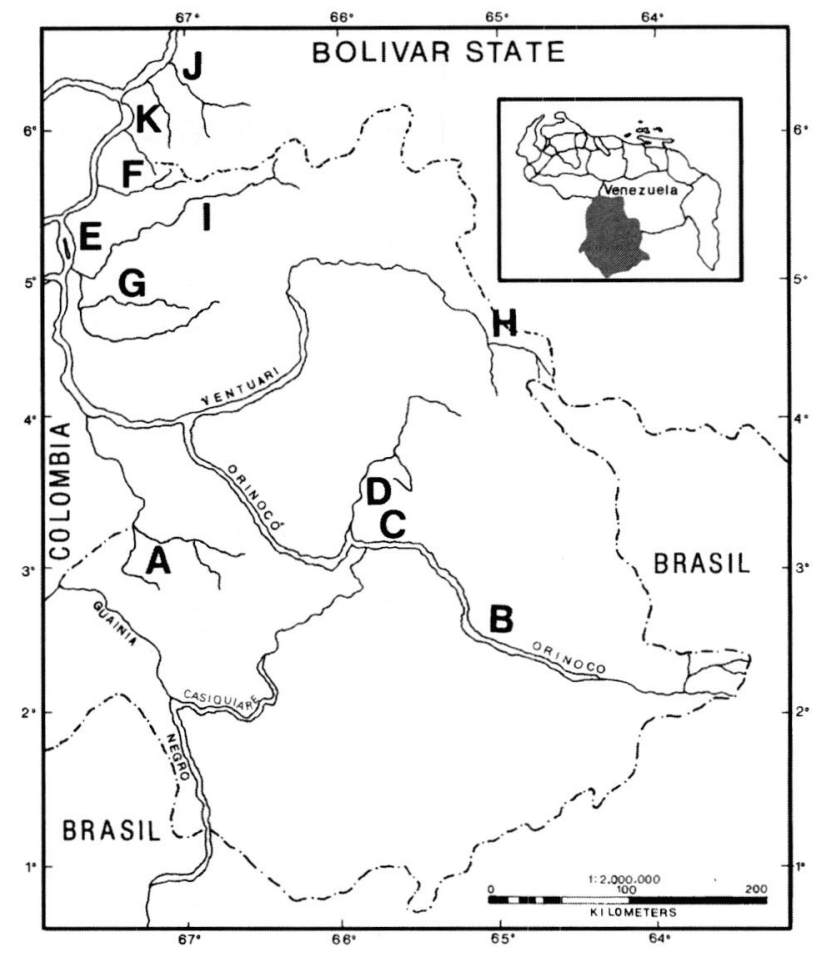

Fig. 1. - Regions where the study was carried out.

A) Temi-Atacavi rivers. B) Upper Orinoco. C) Cejal. D) Cunucunuma river. E) Isla Raton. F) Cataniapo river. G) Cuao, Sipapo, and Autana rivers. H) Upper Ventuari. I) Upper Cuao. J) Parguaza river. K) Topocho stream.

The localities and their environmental characteristics are presented in Table I. The human population studied comprised ethnic groups inhabiting the regions, principally Yanomamis (on the Upper Orinoco), Yekuanas (on the Upper Ventuari and River Cunucunuma), Curripacos, Banivas and Piapocos (on the Temi and Atacavi rivers), and Piaroas and Guajibos (on the Cuao, Sipapo, Autana, Cataniapo and Parguaza rivers and Isla Ratón).

\section{PARASITOLOGICAL METHODS}

A blood sample of $1.0 \mathrm{ml}$ was taken from each person and processed by the Knott technique. The complete tube was then examined, using a ZEISS Standard microscope with $10 \times$ and $40 \times$ magnification. The cases that tested positively for microfilariae were then stained with Mayer's haematoxylin, following the technique described by Denham (1975), and their morphological 


\begin{tabular}{lccl}
\hline \multicolumn{1}{c}{ Localities } & Region & Precipitation $^{\mathbf{1}}$ & \\
\hline Río Temi-Río Atacavi & $\mathrm{A}$ & 3,574 & Vegetation \\
Alto Río Ocamo & $\mathrm{B}$ & 2,607 & Transition amazonian Caatinga/Low lands Pluvial Forest \\
Mavaca-Río Orinoco & $\mathrm{B}$ & 2,479 & Low lands Pluvial Forest \\
Ocamo-Río Orinoco & $\mathrm{B}$ & 2,607 & Low lands Pluvial Forest \\
Platanal-Río Orinoco & $\mathrm{B}$ & 2,479 & Low lands Pluvial Forest \\
Río Mavaca & $\mathrm{B}$ & 2,479 & Low lands Pluvial Forest \\
Cejal-Río Orinoco & $\mathrm{C}$ & 2,632 & Low lands Pluvial Forest \\
Río Cunucunuma & $\mathrm{D}$ & 3,128 & Low lands Pluvial Forest \\
Isla Ratón & $\mathrm{E}$ & 2,183 & Montainous and basimontainous Pluvial Forest \\
Río Cataniapo & $\mathrm{F}$ & 2,571 & Savannah with Riverside Forest \\
Río Autana & $\mathrm{G}$ & 2,533 & Rocky Semideciduous Forest alisio type \\
Río Cuao & $\mathrm{G}$ & 2,533 & Low lands Pluvial Forest with bush \\
Río Sipapo & $\mathrm{G}$ & 2,533 & Low lands Pluvial Forest with bush \\
Alto Río Ventuari & $\mathrm{H}$ & Low lands Pluvial Forest with bush \\
Alto Río Cuao & $\mathrm{I}$ & Semideciduous Forest alisio type \\
Río Parguaza & $\mathrm{J}$ & 2,495 & Montainous and basimontainous Pluvial Forest \\
Caño Topocho & $\mathrm{K}$ & 2,733 & Montainous and basimontainous Pluvial Forest \\
\hline
\end{tabular}

${ }^{1}$ Annual mean (in mm.).

Table I. - Environmental characteristic in the studied localities.

characters were examined for the purposes of taxonomic identification, using $40 \times$ and $100 \times$ objectives.

\section{QUANTITATIVE METHODS}

The quantitative terminology and criteria used are those defined by Kisielewska (1970) and modified by Guerrero (1979, 1996), as follows:

. Prevalence: percentage of infected hosts.

- Relative density: average number of parasites per infected host.

- Absolute density: average number of parasites per host (infected and uninfected).

- Multiple infection: percentage of hosts infected by more than one species of parasite.

- Infection index: a combination of prevalence and absolute density, permitting the determination of the degree of infection of the human groups and regions studied.

It is important to point out here that some authors favour the use of the geometric mean in order to determine parasitic load (density) instead of the arithmetic mean (Brandling-Bennett et al., 1981; Marshall et al., 1974; Sasa, 1976). However, the arithmetic mean, which is employed in the present work, remains a useful measure that provides valid information in the study of filariasis (Sasa, 1976), strictly following the criteria laid down by Kisielewska (op. cit.) and Guerrero (op. cit.).

\section{STATISTICAL ANALYSIS}

For the statistical analysis between the quantitative parameters (Prevalence, both densities and infection index) and rainfall and altitude, the product-moment correlation coefficient (Coefficient for Pearson's corr- relation) was calculated following the procedure described by Sokal \& Rohlf (1969), with data processing carried out by the statistical programme Statgraphics Version $4.0 \mathrm{Co}$.

\section{RESULTS}

I n the samples collected from 1,057 inhabitants of 17 localities, total prevalence was $18.54 \% .11 .26 \%$ were parasited by Mansonella perstans, $9.93 \%$ by Mansonella ozzardi and $2.63 \%$ by both species. The average of microfilaremia was $48.19 \mathrm{mf} / \mathrm{mL}$ of blood in $M$. perstans and $13.79 \mathrm{mf}, \mathrm{mL}$ in $M$. ozzardi.

M. ozzardi was found in $12(70.6 \%)$ of the 17 analysed localities, and $M$. perstans in eight (47.1\%). In five localities (29.41\%) both species were found, while two localities (the Cunucunuma and Mavaca rivers) were free of mansonelliasis. The prevalence was very high in some localities, especially Alto Ventuari (71.21) for M. ozzardi and the Temi and Atacavi rivers (88.16\%) for $M$. perstans (Table II).

The number of circulating microfilariae was low. Generally speaking, in localities where microfilarial density was high the prevalence rate was also high, resulting in an elevated infection index. However, no relation was found between the infection index and multiple infection.

The coefficient for Pearson's correlation shows statistically significant correlations between the quantitative parameters and total average rainfall in the localities studied in the case of $M$. perstans, and altitude in the case of M. ozzardi.

Major differences were found in the distribution of both species of Mansonella in relation to type of vegetation. 


\begin{tabular}{|c|c|c|c|c|c|c|c|c|c|c|}
\hline \multirow[b]{3}{*}{ Localities } & \multirow{3}{*}{$\begin{array}{c}\text { Number } \\
\text { of } \\
\text { cases }\end{array}$} & \multirow{2}{*}{\multicolumn{2}{|c|}{$\begin{array}{c}\text { Prevalence } \\
\%\end{array}$}} & \multicolumn{4}{|c|}{ Density (mf/mL) } & \multirow{2}{*}{\multicolumn{2}{|c|}{ Infection index }} & \multirow{3}{*}{$\begin{array}{l}\text { Multiple } \\
\text { infection }\end{array}$} \\
\hline & & & & \multicolumn{2}{|c|}{ Absolute } & \multicolumn{2}{|c|}{ Relative } & & & \\
\hline & & M. $o^{1}$ & $M \cdot p .^{2}$ & M. o. & M. p. & M. o. & M. p. & M. o. & M. p. & \\
\hline Río Temi-Río Atacavi & 76 & 13.2 & 88.2 & 1.91 & 467.3 & 14.5 & 530.1 & 0.3 & 411.9 & 13.2 \\
\hline Alto Río Ocamo & 38 & 7.9 & 0.0 & 7.0 & 0.0 & 88.0 & 0.0 & 0.6 & 0.0 & 0.0 \\
\hline Mavaca-Río Orinoco & 82 & 18.3 & 0.0 & 2.4 & 0.0 & 12.9 & 0.0 & 0.4 & 0.0 & 0.0 \\
\hline Ocamo-Río Orinoco & 35 & 5.7 & 0.0 & 4.2 & 0.0 & 73.5 & 0.0 & 0.2 & 0.0 & 0.0 \\
\hline Platanal-Río orinoco & 47 & 14.9 & 0.0 & 2.3 & 0.0 & 15.1 & 0.0 & 0.3 & 0.0 & 0.0 \\
\hline Río Mavaca & 66 & 0.0 & 0.0 & 0.0 & 0.0 & 0.0 & 0.0 & 0.0 & 0.0 & 0.0 \\
\hline Cejal-Río Orinoco & 30 & 3.3 & 0.0 & 0.4 & 0.0 & 13.0 & 0.0 & 0.1 & 0.0 & 0.0 \\
\hline Río Cunucunuma & 82 & 0.0 & 0.0 & 0.0 & 0.0 & 0.0 & 0.0 & 0.0 & 0.0 & 0.0 \\
\hline Isla Raton & 60 & 3.3 & 0.0 & 5.4 & 0.0 & 162.5 & 0.0 & 0.2 & 0.0 & 0.0 \\
\hline Río Cataniapo & 119 & 2.52 & 17.7 & 0.7 & 39.6 & 29.3 & 224.4 & 0.1 & 7.0 & 2.5 \\
\hline Río Autana & 8 & 12.5 & 12.5 & 4.3 & 1.0 & 34.0 & 8.0 & 0.5 & 0.1 & 12.5 \\
\hline Río Cuao & 50 & 2.0 & 4.0 & 0.1 & 1.5 & 3.0 & 37.0 & 0.002 & 0.1 & 2.0 \\
\hline Río Sipapo & 27 & 0.0 & 3.7 & 0.0 & 0.6 & 0.0 & 15.0 & 0.0 & 0.1 & 0.0 \\
\hline Alto Río Ventuari & 66 & 71.2 & 0.0 & 193.9 & 0.0 & 272.3 & 0.0 & 138.1 & 0.0 & 0.0 \\
\hline Alto Río Cuao & 67 & 19.4 & 31.3 & 6.9 & 150.4 & 35.4 & 479.8 & 1.3 & 47.1 & 19.4 \\
\hline Río Parguaza & 170 & 0.0 & 2.4 & 0.0 & 2.7 & 0.0 & 116.5 & 0.0 & 0.1 & 0.0 \\
\hline Caño Topocho & 34 & 0.0 & 5.9 & 0.0 & 2.1 & 0.0 & 36.0 & 0.0 & 0.1 & 0.0 \\
\hline
\end{tabular}

${ }^{1}$ Mansonella ozzardi.

${ }^{2}$ Mansonella perstans.

Table II. - Quantitative results in the studied localities.

\begin{tabular}{lcc}
\hline \multicolumn{1}{c}{ Criteria } & Precipitation & Altitude \\
\hline Prevalence $M$. ozzardi & -0.6930 & 0.897 \\
& $(0.792)$ & $(0.000)^{*}$ \\
Prevalence $M$. perstans & 0.7233 & -0.140 \\
& $(0.001)^{*}$ & $(0.591)$ \\
Absolute density $M$. ozzardi & -0.1169 & 0.923 \\
& $(0.655)$ & $(0.000)^{*}$ \\
Absolute density $M$. perstans & 0.7518 & -0.093 \\
& $(0.001)^{*}$ & $(0.723)$ \\
Relative density $M$. ozzardi & -0.2953 & 0.717 \\
& $(0.250)$ & $(0.001)^{*}$ \\
Relative density $M$. perstans & 0.5479 & -0.082 \\
& $(0.023)$ & $(0.754)$ \\
Infection index $M$. ozzardi & -0.1064 & 0.921 \\
Infection index $M$. perstans & $(0.685)$ & $(0.000)^{*}$ \\
& 0.7916 & -0.113 \\
& $(0.000)^{*}$ & $(0.666)$ \\
\hline
\end{tabular}

* Correlation $(\mathrm{P}=0.001)$.

Table III. - Pearson's correlation coefficients between quantitative criteria and environmental variables.

M. ozzardi evidences a higher infection index in those regions which have Alisio-type semi-deciduous forest, while $M$. perstans is higher in Amazonian caatinga transition in pluvial lowland forest.

\section{DISCUSSION}

The results of this study confirm that mansonelliases is widespread in Amazonas State and the neighbouring areas of Bolivar State, in the south of Venezuela.
The main focuses are in the regions of the Temi and Atacavi rivers with an infection index (i.i.) of 413.52, and in Upper Ventuari (i.i. $=138.09$ ).

The former undoubtedly represents an extension of the focus described by Formica \& Botto (1990) in Venezuela and Kozek et al. (1982a) in Colombia, a focus in which $M$. perstans must be endemic. Apart from the dominance of $M$. perstans, this focus is characterised by high prevalence and an elevated percentage of inhabitants parasited by both species of Mansonella.

The Upper Ventuari focus is probably an extension of the one described by Godoy et al. (1980) in the southwest of Bolivar State, and is due to M. ozzardi.

Lesser infestations occur in the regions of the Upper Cuao (i.i. $=49.33$ ) and River Cataniapo (i.i. = 7.12). Both of these regions were reported as focuses of mansonelliasis by Baumgartner (1955). The remaining localities studied had infection indexes of less than one (1.0). M. ozzardi was spread over a wider area than $M$. perstans, the latter being distributed in the north-west of Amazonas State, from the Temi and Atacavi rivers to north of Puerto Ayacucho, on the Cuao, Sipapo and Autana rivers, and in neighbouring localities in Bolivar State.

M. ozzardi is found to the east and south-east of the Temi and Atacavi rivers as far as the Upper Orinoco, and in the regions near to the mouth of the Casiquiare river, where mansonelliasis has previously been reported (Beaver et al., 1976).

Overlapping of both species, and consequently multiple infection, occurs in the regions of the Temi, Atacavi, Autana, Cuao and Cataniapo rivers. 


\begin{tabular}{|c|c|c|c|c|c|c|}
\hline \multirow[b]{2}{*}{ Vegetation types } & \multicolumn{3}{|c|}{ M. ozzardi } & \multicolumn{3}{|c|}{ M. perstans } \\
\hline & Prevalence & A. den. ${ }^{1}$ & Inf. Ind. ${ }^{2}$ & Prevalence & A. den. & Inf. ind. \\
\hline $\begin{array}{l}\text { Transition amazonian Caatinga/Low lands } \\
\text { Pluvial Forest }\end{array}$ & 13.16 & 1.91 & 0.25 & 88.16 & 467.29 & 411.29 \\
\hline Low lands Pluvial Forest & 9.40 & 2.43 & 0.23 & 0.00 & 0.00 & 0.00 \\
\hline Low lands Pluvial Forest with bush & 2.35 & 0.44 & 0.01 & 4.71 & 1.14 & 0.05 \\
\hline $\begin{array}{l}\text { Mountainous and basimountainous Pluvial } \\
\text { Forest }\end{array}$ & 4.08 & 1.44 & 0.06 & 7.84 & 33.04 & 2.59 \\
\hline Rocky semideciduous Forest alisio type & 1.96 & 0.58 & 0.01 & 15.03 & 31.27 & 4.70 \\
\hline Savannah with Riverside Forest & 3.33 & 5.42 & 0.18 & 0.00 & 0.00 & 0.00 \\
\hline Semideciduous Forest alisio type & 71.21 & 193.91 & 138.08 & 0.00 & 0.00 & 0.00 \\
\hline
\end{tabular}

${ }^{1}$ Absolute density

${ }^{2}$ Infection Index.

Table IV. - Values of qualitative criteria of Mansonella spp. according with the types of vegetation.

The quantitative criteria of prevalence, absolute density and infection index calculated for $M$. perstans evidenced a high correlation to precipitation in each locality, rainfall being the most influential environmental variable for the transmission of this species. This is probably due to the conditions required by the vector: in relative humidity or continuous rain, seasonal effects are eliminated, which produces a more efficient, ongoing transmission of the filaria.

In the case of $M$. ozzardi the correlation is with altitude: in other words, the most effective vectors for transmitting this species are found in localities in higher regions.

With respect to types of vegetation, transmission of M. perstans is most favoured by Amazonian caatinga transition in lowland pluvial forest, while $M$. ozzardi is favoured by alisio-type semi-deciduous forest.

These results confirm that the two species of Mansonella require different environmental conditions for their transmission, and probably have different vectors in natural conditions.

Laboratory studies reveal that Culicoides spp. and Simulium spp. can act as vectors for M. ozzardi (Tidwell \& Tidwell, 1982). In natural conditions it is likely that Simulium is the vector for M. ozzardi and Culicoides for $M$. perstans. It is supported by field observations, in localities with dominance of $M$. ozzardi, species of Simulium were abundant and in localities with dominance of $M$. perstans, Culicoides ever were present. Larvae and pupae of Simulidae need fast runing waters (Wygodzinsky \& Coscarón, 1989) as usually are in localities in higher regions were $M$. ozzardi is dominant. In conclusion, mansonelliases is widespread in Amazonas State, the main focuses in the localities studied being situated on the Temi and Atacavi rivers and the Upper Ventuari, with M. ozzardi having a wider distribution than $M$. perstans. The latter species evidences a greater transmission rate in areas of higher rainfall, while the transmission of $M$. ozzardi is favoured by higher altitude. The two species also evidence different transmission rates with respect to the types of vegetation studied, probably because the respective types of vegetation favour the development of the corresponding vectors for these filariae.

\section{ACKNOWLEDGEMENTS}

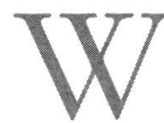

e would like to thank Miguel Conde, Mayila García and Manuel Bolivar for their help in the laboratory and with field work; Carlos Noguera for his advice and suggestions; Dr Carlos Botto for his support in the last stages of this work; and Tibisay Rangel for her help and collaboration at all times. This research received financial support from the Consejo Nacional de Investigaciones Científicas y Tecnológicas (CONOCIT) of Venezuela, through grant no. S1-2014.

\section{REFERENCES}

BAUmgartner J. Noticia acerca de la microfilaria por Mansonella ozzardi en el Territorio Federal Amazonas. Boletin Indigenista Venezolano, 1955, 3, 379-402.

Beaver P.C., Neel J.V. \& Orihel T.C. Dipetalonema perstans and Mansonella ozzardi in indians of Southern Venezuela. American Journal of Tropical Medicine and Hygiene, 1976, 25, 263-265.

BOADAs A.R. Geografia del Amazonas Venezolano. Editorial Ariel-Seix Barral Veneolana, Caracas, 1983, 85 p.

Botto C., Yarzabal A., Lugo E., Arango M. \& Yarzabal L. Aspectos epidemiologicos de la Mansonelosis en el Territorio Federal Amazonas, Venezuela, in: Las filariasis humanas en el Territorio Federal Amazonas (Venezuela). Editorial Proicet Amazonas, Caracas, 1983, Publicacion Cientifica No. 2, 21-40. 
Brandling-Benett A.D., Anderson J., Fuglsang H. \& Coluins R. Onchocerciasis in Guatemala. Epidemiology in Fincas with various intensities of infection. American Journal of Tropical Medicine and Hygiene, 1981, 30, 970-981.

Denham D.A. Counting and identifying of microfilariae. A Laboratory Manual. London School of Hygiene and Tropical Medicine, London, 1975.

Formica S. \& Botto C. Filariasis focus due to Mansonella ozzardi and Mansonella perstans in the Amazon Federal Territory of Venezuela. Journal of Tropical Medicine and Hygiene, 1990, 93, 160-165.

Godoy G.A, Volcan G., Medrano C., Teixeira A. \& Matheus L. Mansonella ozzardi infections in indians of the southwestern part of the state of Bolivar, Venezuela. American Journal of Tropical Medicine and Hygiene, 1980, 29, 373376.

GUERRERO R. The structure of the endoparasites belminth communities of rodent in an urban gradient. $\mathrm{Ph} \mathrm{D}$. Thesis, Polish Academy of Sciences, Wasaw, 1979, 121 p.

GUERRERO R. Estudio preliminar de los ectoparasitos de los murcielagos de Pakitza, Parque Nacional Manu (Peru), in: The Biodiversity of Southeastern Peru. Wilson D.E. \& Sandoval A. (eds.). Smithsonian Institution, Washington, 1996, pp. 619-634.

HAwKING F. The distribution of human filariasis throughout the world. Part IV. America. Tropical Diseases Bulletin, 1979, 76, 693-710.

Huber O. Esbozo de las formaciones vegetales del Territorio Federal Amazonas, Venezuela. Serie Informe Tecnico DGSIIA/IT/103. Ministerio del Ambiente y los Recursos Renovables, Caracas, 1982.

KIsIELEwSKa K. On the theoretical foundations of Parasitosynecology. Bulletin de l'Académie Polonaise des Sciences, Série C, 1979, 18, 103-106.

KozeK W.J., D'Alessandro A. \& Hoyos M. Filariasis in Colombia: presence of Dipetalonema perstans in the Comisaria del Guainia. American Journal of Tropical Medicine and Hygiene, 1982a, 31, 486-489.

KozeK W.J., D'Alessandro A., Silva J., \& Navarrete S. Filariasis in Colombia: prevalence of mansonelliasis in the teenage and adult population of the colombian bank of the amazon, Comisaria del Amazonas. American Journal of Tropical Medicine and Hygiene, 1982b, 31, 1131-1136.

Marshall T.F. de C., Hamilton P.J.S., Fuglsang H. \& AnderSON J. Logarithmic density as a measure of infection of the skin in onchocerciasis. World Health Organization. WHO/ $\mathrm{ONCHO} / 74.111,1974$.

Manson P. The Filaria sanguinis hominis major et minor two new species of Hematozoa. Lancet, 1891, 1, 4-8.

Manson P. On certain new species of nematode haematozoa ocurring in America. British Medical Journal, 1897, 2, 18371838.

RACCURT C., LOWRIE R.C. Jr \& MCNEeley D.F. Mansonella ozzardi in Haiti. I. Epidemiological survey. American Journal of Tropical Medicine and Hygiene, 1980, 29, 803-808.

SASA M. Human Filariasis. A global survey of Epidemiology and Control. University of Tokyo Press, Tokyo, 1976, 819 p.
SOKal R.R. \& Rohlf F.J. Biometry. Principles and practice of statistic in biological reseach. FreemanW.H. and Co., San Francisco, 1969, 776 p.

Tidwell M.A. \& Tidwell M.A. Development of Mansonella ozzardi in Simulium amazonicum, S. argentiscutum, and Culicoides insinuatus from Amazonas, Colombia. American Journal of Tropical Medicine and Hygiene, 1982, 31, 1137-1141.

WYGODZINSKY P. \& COSCARÓN S. Revision of the black fly genus Gigantodax (Diptera:Simulidae). Bulletin of the American Museum of Natural History, 1989, 189, 1-269.

Reçu le 21 avril 1999 Accepté le 18 février 2000 